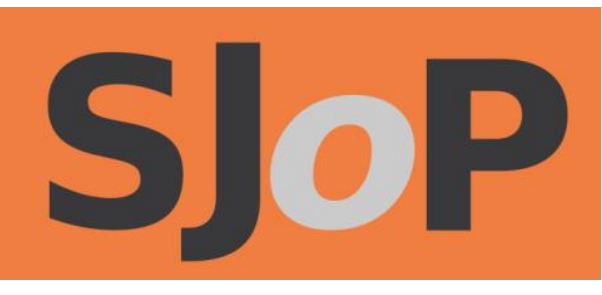

\title{
You do not have to walk on your knees
}

\section{PETER MCMASTER}

The Scottish Journal of Performance

Volume 5, Issue 1; April 2018

ISSN: 2054-1953 (Print) / ISSN: 2054-1961 (Online)

Publication details: http://www.scottishjournalofperformance.org

To cite this article: McMaster, P., 2018. You do not have to walk on your knees. Scottish Journal of Performance, 5(1): pp.157-169.

To link to this article: http://doi.org/10.14439/sjop.2018.0501.15

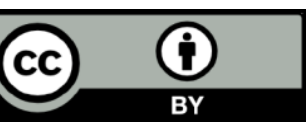

This work is licensed under a Creative Commons

Attribution 4.0 International License. See

http://creativecommons.org/licenses/by/4.0/ for details. 


\section{You do not have to walk on your knees}

PETER MCMASTER

DOI: $10.14439 /$ sjop.2018.0501.15

Publication date: 6 April 2018

I am an experimental performance maker who lives in Glasgow. In my role as listener-in-residence for the Art of Care-full Practice symposium, I decided that the most care I could exercise in my role would be to present back to the audience an unadulterated account of what I had heard throughout the day; words either directly extracted from a talk, from a passing conversation, or something I might have overheard walking down the corridor or whilst having lunch. I was aware of not wanting to process any material I heard through my own personal frames of reference, at least not consciously. I feel a particular responsibility in this regard as a male maker. As a white cisgendered man, I am constantly battling a sense of entitlement and the ways in which I occupy, or inadvertently command space. In a small way, I wanted my experience as a listener to allow other people's thoughts and experiences to occupy me, and to reflect back that experience in the text I compiled and eventually read out aloud.

At the start, I hear statements.

Love is analogous to genius.

Fluffy, touchy, feely.

I hear questions. 
Scottish Journal of Performance

Volume 5, Issue 1

How do we practise care?

Is this writing for me, rather than at me?

There's a man talking, and he's thinking of us.

There's a woman, and she's making room for a reply.

I feel an onslaught of academia.

Effective, ethical and practical.

There's a man, talking about a man who's alluding to the male gaze.

A man talking about this father, thinking about a fortunate man. About another man who ended up taking his own life.

A seventh man.

I am a man.

Dismantling and reassembling.

Thinking feelingly, and feeling thinkingly.

(I have a memory of my younger sister's friend, who was bullied so badly she stopped eating and ended up in hospital. 
When my Mum tells me in our utility room, I burst out crying and she holds me.)

There's a woman, and she's thinking a lot about care, and about who benefits.

gHosting with a capital $\mathrm{H}$.

Hosting.

There are Freud case histories, and she is erasing the doctor.

I hear about the man who said:

'Your work means nothing to me', and then leaves.

I hear a woman, talking about and speaking of women.

About learning how to take care of one's self when taking risks. Taking risks, taking care.

Pink words on paper, like the enigma code book.

I hear about Sophie Calle, and the 'break-up email'.

Taking time, taking care. 
Scottish Journal of Performance

Volume 5, Issue 1

The rhetoric of care is the work, not separate to the work...

but what matters is what works.

Then there's talk about time and money.

A king interrupts a queen, and he is blind.

(I am wondering how long I have dominated the arm rest in this cinema auditorium.)

She says that Calle speaks of sisterhood.

This woman talks about a woman talking about women.

What is hidden should be exposed.

And now there is another man.

Now there are a lot more words. 
I hear my brain cogs whirring, concentrating.

Tell it like it is!

I think I need the safe zone.

Another man talks about another man.

About how need is contextual, not prescriptive.

And then I hear about care in a non-place.

I hear a quivering voice talking about feelings.

It's all allowed.

These are sensitive translations.

He says space is movement, place is pause.

I think I'm getting this.

I'm not often in thinky places like this. 
Scottish Journal of Performance

Volume 5, Issue 1

Feeling reflects the way the internal world is affected. I get this.

There are consequences to what we do.

But when the truth slips, you're lost; lost in $18 \mathrm{~cm}$ of intimate space.

There's a woman, and she finds this hard.

Acts of self-care become embarrassing.

Her voice shakes, she feels vulnerable.

Break, weakness.

Too much infinite energy.

I think, 'treat yourself like one of your participants'.

Think self-indulgence.

Self-preservation.

We have to. 
It's all allowed.

The world is such a mess!

It's political warfare.

It's a state of fear.

You don't need this.

We don't need this.

And then a queer woman talks of Donald Trump and Theresa May.

This time, punishing yourself won't solve anything.

Cuts, and cutting yourself off.

Knowing how to live isn't easy.

Neither is cutting out space. 
Scottish Journal of Performance

Volume 5, Issue 1

You are not a bad person.

You say domestic models are inspired by caring.

Including breakfast. She needs to have it; if she doesn't, she won't have the energy to care for her children.

It's art as maintenance.

But then, sometimes the artists who are asked to care the most are exploited the most heavily.

Why does talking about self-care feel so hard? Surely it should feel... lovely?

Progress is a path inwards, not bums on seats, not box office returns.

And then I hear bird song,

wind,

dogs barking. 
She says, 'I get up, and I do what I want to do.

It's absolutely phenomenal. You can see for miles and miles, I wonder if someone is watching over me?

Trust me, it's hard.

It's hard.

It's not dismissing my life or making any less of my life.

But if someone tells you you're terminal, the thing you have to face up to essentially is that you have no future.

I have to be, not because I want to be'.

And now I am listening to stuff about Adrian Howells.

And now I am listening to Adrian's obituary.

And now I am listening to Adrian and the Carpenters.

Karen Carpenter.

It's Yesterday once more. 
Scottish Journal of Performance

Volume 5, Issue 1

I'm listening to a second video today in which the subject is deceased.

Bring it back to care-full practice.

I don't know what to say.

(I'm listening to my memory of Adrian staying in my home when he couldn't take care of himself.)

And then there was silence, for a while.

I hear her say that she places listening at the heart of what she does.

And then I notice she has a sticker of an ear placed just over her heart.

There it is again, a work for someone at the end of their life. 
I hear breath and crow calls.

Is it a murder of crows?

Or was that ravens?

I hear:

A laugh.

A sigh.

A scream.

A sobbing.

A voice becoming bird song.

It really is happening, it is great, and it makes me care about her project.

And then back to care-full practice. 
Scottish Journal of Performance

Volume 5, Issue 1

And I listen as she says,

'You

Do

Not

Have

To

Walk

On

Your

Knees'. 


\section{About the author}

PETER MCMASTER's practice includes directing, performing, solo and intimate performance, mentorship, collaboration and facilitating within the making of live experimental performance in and beyond the UK. As an artist, Peter has a pedagogical approach that he lives through working in educational contexts, and he has delivered professional development opportunities for other artists. His concerns as an artist are to obfuscate contemporary typical masculine identities, as well as to find sustainability and appreciation within the life of being an artist and a resident of planet earth. Peter has toured nationally and internationally; he has conducted international research commissions, and he holds positions of consultation on the boards of venues and festivals. 